\title{
Üniversite Öğrencilerinin Gelecekte Çocuk Sahibi Olmaya İlişskin Düşünceleri ve Etkileyen Faktörler
}

\author{
Nurgül ŞiMAL*, Elif GÜRSOY**
}

Öz

Giriş: Çocuk sahibi olmak sosyo-kültürel, psikolojik ve ekonomik boyutları olan çok yönlü toplumsal bir olgudur. Amaç: Araştırma, farklı sosyo-demografik özelliklere sahip üniversite öğrencilerinin gelecekte çocuk sahibi olma düşüncesi ve etkileyen faktörleri belirlemek amacıyla yapılmıştır. Yöntem: Tanımlayıcı olarak yapılan araştırmanın evrenini, Eskişehir'de bulunan bir üniversitede öğrenim gören 9.208, örneklemini ise 712 son sınıf öğrencisi oluşturdu. Veriler, Ocak-Şubat 2019 tarihleri arasında veri toplama formu ile toplanmıştır. Verilerin analizinde frekans, ortalama ve ki-kare testi kullanılmıştır. Bulgular: Öğrencilerin \%77.9'unun ileride çocuk sahibi olmak istediğ saptanmıştır. Öğrencilerin sahip olmak istediği çocuk sayısı ortalama 2.18 'dir ve istenen çocuk sayısının cinsiyete göre farklılık göstermediği belirlenmiştir. Öğrencilerin gelecekte çocuk sahibi olma düşüncesini etkileyen faktörler arasında ilk üç sırada psikolojik iyilik, soyun devamı ve bireysel karar verme geldiği saptanmıştır. Öğrencilerin gelecekte çocuk sahibi olma düşüncesini etkileyen faktörler ile cinsiyet, aile tipi, en uzun süre yaşadıkları yer arasında istatistiksel olarak anlamlı bir fark bulunurken; anne ve baba eğitim durumu ile fark bulunmamıştır. Sonuç: Öğrencilerin gelecekte çocuk sahibi olma düşüncesi üzerinde etkili olan faktörlerin başında çocuğun psikolojik yönü, soyun devamı ve kişilere ait bireysel tercihin geldiği saptanmıştır. Öğrencilerin büyük çoğunluğunun ekonomik özgürlüğe kavuşmadan çocuk sahibi olmak istemediği belirlendi. Geniş aile tipine sahip ve en uzun süre yaşadığı yer köy olan öğrencilerin daha fazla sayıda çocuk sahibi olmak istedikleri, erkek çocuk algısını daha yoğun yaşadıkları ve soyun devamı açısından çocuğun önemine daha çok inandıkları saptanmıştır. Çalışmada kır-kent ayrımı belirgin şekilde ortaya çıkarken, anne-baba eğitim durumlarının çocuk sahibi olma isteği üzerinde anlamlı etkisinin olmadığı belirlenmiştir.

Anahtar Sözcükler: Çocuk Sahibi Olmak, Üniversite Öğrencileri, Gençlik.

\section{Abstract \\ Thoughts of University Students on Having Children in the Future and Affecting Factors}

Background: Having children is a multifaceted social phenomenon with socio-cultural, psychological and economic dimensions. Aim: The research was carried out to determine the future thinking of university students with different socio-demographic characteristics and the factors affecting them. Method: While the universe of this descriptive study consisted of 9208 students studying at a university in Eskisehir, the sample of the study consisted of 712 senior students. Data were collected between January-February 2019 using a data collection form. Frequency, mean and chi-square testing were used in the analysis of the data. Results: It was found that $77.9 \%$ of students wanted to have children in the future. The average number of children that the students wanted to have was 2.18 and it was determined that the desired number of children did not differ by the gender. Psychological well-being, the continuation of lineage, and individual decision making were the top three factors among the factors affecting students' the idea to have children in future. While there was a statistically significant relationship between the factors affecting students' the idea to have children in future and gender, family type, place of residence for the longest period, no significant difference was found between these factors and the education level of the mother and father. Conclusion: The psychological aspect of the child, the continuation of lineage, and the individual-social preference of individuals were found to be the major factors affecting students' the idea to have children in future. It was found that the majority of students did not want to have children before becoming self-supporting. It was found that the students who had large families and who lived in the village for the longest period in their lives wanted to have more children, they had the perception of a son more intensively, and they believed about the importance of the child more for the continuation of the lineage. In the study, while the distinction between the rural and urban areas was revealed, it was determined that the educational status of parents did not have a significant effect on the desire to have children.

Key Words: Having Children, University Students, Youth.

\section{Geliş tarihi: 21.01.2020 Kabul tarihi: 17.06.2020}

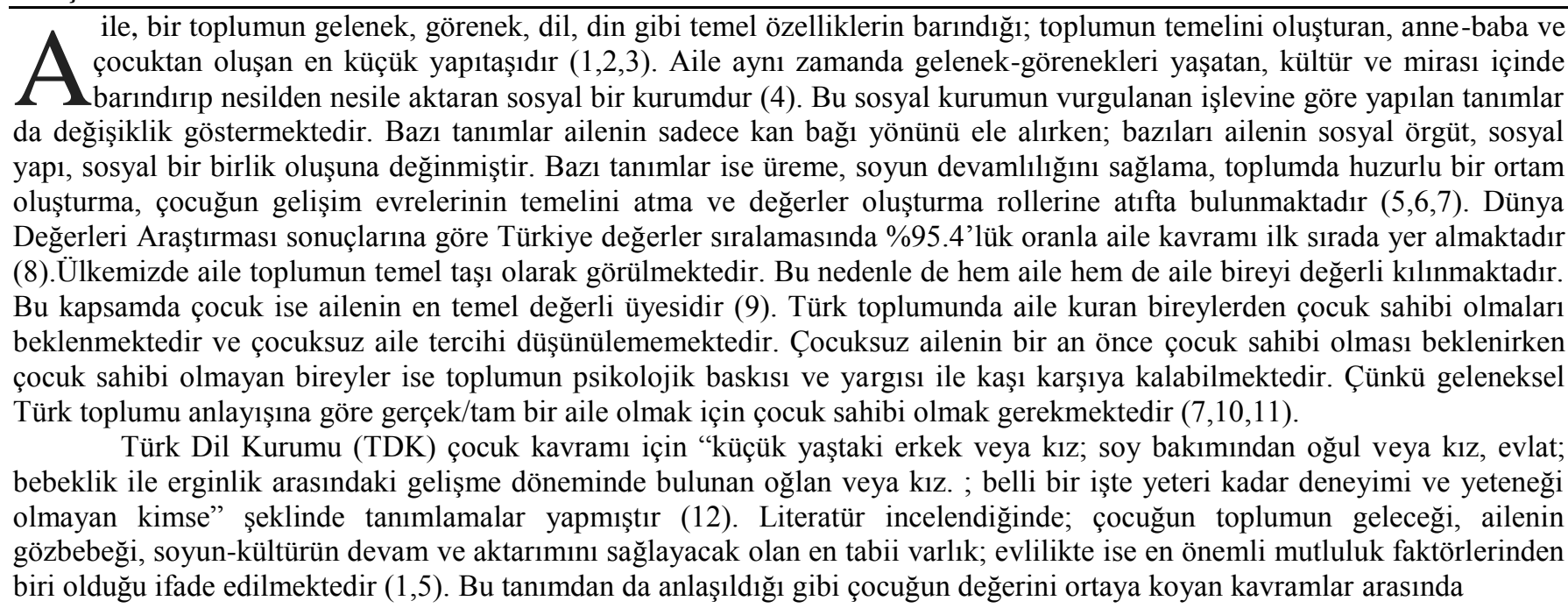

*Doktora Öğrencisi, Eskişehir Şehir Hastanesi, 1. Basamak Yoğun Bakım Servisi, Eskişehir, https://orcid.org/0000-0002-0817-0640, e-mail: nurgulsimal@gmail.com ** Doç. Dr. Eskişehir Osmangazi Üniversitesi Hemşirelik Fakültesi Doğum ve Kadın Sağlığı Hemşireliği Anabilim Dal, Eskişehir, https://orcid.org/0000-0003-0147-8682, e-mail: elif070@ gmail.com 
toplumun geleceği, soyun devamı ve ailenin mutluluğu öne çıkmaktadır. Çocuk aile olabilmenin tamamlayıcı niteliğinde görülen önemli bir olgudur (13). Bazı toplumlarda olduğu gibi bizim toplumumuzda da çoğu kez evlilik çocuk sahibi olmakla eşdeğer görülebilir ve evliliğin devamı için çocuk sahibi olmanın önemli bir faktör olduğu inancı hakim olabilmektedir $(3,11,13)$. Y1llar içerisinde ve toplumdan topluma çocuğa atfedilen değer değişmekle birlikte hem ülkemizde hem dünyada yapılan çalışmalar çocuğun ailede ve toplumda değiştirilemez bir temel değere sahip olduğunu göstermektedir. Bu değişim çocuğun cinsiyetine, aile tipine-yerleşim yerine ve de toplumun modern-geleneksel yapısına göre değişim yaşamış fakat çocuk sahibi olmaya verilen önem ve değer her daim yerini korumuştur $(7,10,13)$. Toplumsal temelli çalışmalara göre bireylerin çocuk sahibi olmayı isteme nedenlerinin temelinde geleneksel aile yapısı, toplumsal kabul, kalıplaşmış rol ve sorumluluklar ve birtakım toplumsal cinsiyet algıları etkili olmaktadır.

Üniversite öğrencileri toplumun gelişen, değişen ve geleceğe yön veren grubunu oluşturmaktadır. Gençlere çocuk sahibi olmadan önce gerekli farkındalığın ve bilincin kazandırılması sağlıklı toplumlar sağlamak noktasında önemli bir adım olmakla birlikte; farkındalığı yüksek ve bilinçli bireylerin sahip olacağı bilinçli çocuk sahibi olma yolculuğu onları ileriki dönemlerinde sağlıklı karar vermeye yardımcı olacaktır. Bu kapsamda özellikle hemşireler sahada hastane, aile sağlığı ve toplum sağlığı merkezlerinde; akademide ise üniversiteler ve akademik birçok platformda gençleri bu konuda bilinçlendirme noktasında en önemli rol alacak kişilerden biridir. Literatür incelendiğinde üniversite öğrencilerinin çocuk sahibi olma düşüncelerine ilişkin sınırlı sayıda çalışmaya rastlanmış ve bu açıdan çalışma planlanmıştır. Çocuk sahibi olmaya yönelik yaklaşım ve düşüncelerin belirlenmesi ise aile yapısı, gelecek planlaması, toplum yapısının analizi, nüfus politikaları gibi konularda rehberlik etmesi açısından önemlidir. Çünkü çocuk sahibi olmak konusunda bilinçli gençlerin yetişmesi gelecekte bilinçli anne baba adayları olarak sağlıklı toplumun temellerini atma açısından önem arz etmektedir. Bu nedenle bu çalışmada öğrencilerin çocuk sahibi olmaya ilişkin düşünceleri ve bu düşüncelerini etkileyen faktörler incelenmiştir.

Amaç

$\mathrm{Bu}$ araştırma, farklı sosyo-demografik özelliklere sahip üniversite öğrencilerinin gelecekte çocuk sahibi olma düşüncesi ve etkileyen faktörlerin belirlenmesi amacıyla yapılmıştır.

\section{Araştırma sorulart}

1.Üniversite öğrencileri gelecekte çocuk sahibi olmak istiyor mu?

2.Üniversite öğrencilerinin gelecekte çocuk sahibi olma düşüncesini etkileyen faktörler nelerdir?

3.Üniversite öğrencilerinin gelecekte çocuk sahibi olma düşüncesini etkileyen faktörler ile sosyo-demografik özellikleri arasında ilişki var mı?

\section{Yöntem}

\section{Araştırmanın Tipi}

Araştırma, tanımlayıcı türde planlanmış ve uygulanmıştır.

\section{Araștırmanın Yeri ve Zamanı}

Ocak 2019- Şubat 2019 tarihleri arasında Eskişehir'de bir devlet üniversitesi bünyesinde yer alan fakültelerde yapılmıştır.

\section{Araştırmanın Evreni ve Örneklemi}

Araştırmanın evrenini üniversite bünyesinde yer alan toplam 11 fakülte 48 bölümde, 2018-2019 eğitim-öğretim y1lında öğrenim gören 9.208 son sınıf öğrencisi oluşturmuştur. Araştırmanın örneklemini hesaplarken her bölümden aynı oranda örnek seçmek amacıyla "orantılı tabakalı örnekleme" yöntemi kullanılmıştır. Yapılan analizde güven düzeyi, hata payı (\%95 güven aralığı, \%5 hata payı, \%50 görülme sıklığı) ve evreni bilinen örneklem formülü kullanılmış ve minimum 369 öğrenciye ulaşılması gerektiği belirlenmiştir. Çalışma konusunun kültürel boyutu göz önünde tutularak örneklem sayısının yaklaşık iki katına (738) ulaşılmaya çalışılmıştır. Toplamda 740 öğrenciye ulaşılmış, eksik doldurulmuş olan 28 form çalışmaya dahil edilmemiştir. Elde edilen örneklem sayısının PASS 11 paket programı ile yapılan güç analizi sonucunda 0.999 güce ulaşıldığı belirlenmiş ve çalışma sonlandırılmıştır. Çalışma 364 erkek ve 348 kadın olmak üzere toplam 712 kişi ile tamamlanmıştır.

Araştırmanın değişkenleri

Bă̆ımlı Değişkenler: Gelecekte çocuk sahibi olma düşüncesi ve etkileyen faktörler

Bă̆ımsız Değişkenler: Sosyo-demografik özellikler

\section{Veri Toplama Araçlart}

Veriler araştırmacı tarafından literatür doğrultusunda $(11,14,15,16,17,18)$ geliştirilen, 2 bölümden ve 47 sorudan oluşan veri toplama formu ile yüz yüze görüşme tekniği ile toplanmıştır. Veri toplama formu oluşturulurken alanları sosyoloji (1), istatistik (1), ebelik (1) ve kadın hastalıkları ve doğum hemşireliği (1) olan dört farklı kişiden uzman görüşü alınmıştır.

Birinci bölümde öğrencilerin tanıtıcı özelliklerine (yaş, cinsiyet, aile tipi, en uzun süre yaşadığı yer, anne-baba eğitim durumu ve mesleği, kardeş sayısı, ideal çocuk sayısı, çocuk sahibi olmak için ideal yaş aralığı) ilişkin tanıtıcı bilgilerin yer aldığ 1 toplam 14 sorudan oluşmuştur.

İkinci bölümde, öğrencilerin gelecekte çocuk sahibi olma düşüncesini etkileyen faktörleri içeren ifadelerin yer aldığ1, toplam 33 soru yer almaktadır. Literatürde yer alan sınırlı sayıdaki çalışma ve uzman görüşü alınarak oluşturulan veri toplama formunun ikinci kısmı; temeli sosyo-kültürel, ekonomik ve psikolojik tabana dayanan alt sorulardan oluşturulmuştur (Bireysel karar verme, aile hayatının devamı, psikolojik iyilik, soyun devamı, ekonomik yeterlilik, statü kazanmak, erkek çocuk alg 1 sı, aile ve çevre baskısı, aile işlerine destek, gelecek garantisi, dini inançlar). Hazırlanan veri toplama formunun öğrenciler tarafından anlaşılırlığını ve form doldurma süresini belirlemek amacıyla; rastgele 3 fakültenin kantininde son sınıf öğrencileri 
arasından seçilen 10 üniversite öğrencisi ile pilot çalışma yapılmıştır. Yapılan pilot çalışma sonucunda, veri toplama formunda gerekli düzenlemeler yapılarak forma son şekli verilmiştir. Bu öğrenciler örneklemin dışında tutulmuştur.

Araştırma verileri yüz yüze görüşme tekniği ile ders saatleri dışında toplanmıştır. Araştırmanın amacı açıklandıktan sonra öğrencilerin sözlü onamları alınmış ve formlar dağıtılmıştır. Formların doldurulması yaklaşık 15-20 dakika sürmüştür.

\section{Verilerin Değerlendirilmesi}

Araştırmadan elde edilen verilerin analizi IBM SPSS 23.0 (IBM Statistical Package for the Social Sciences) paket programı ile yapılmıştır. Veriler değerlendirilirken kategorik değişkenler için frekans dağılımları kullanılmıştır. Tanımlayıcı istatistikler; sayı, yüzde, ortalama ve standart sapma ile değerlendirilmiştir. İki değişken arasındaki ilişkinin istatistiksel olarak anlamlı olup olmadığını belirlemek için ki-kare bağımsızlık testi uygulandı. İstatistiksel anlamlılık $\mathrm{p}<.05$ düzeyinde değerlendirilmiştir.

\section{Araştırmanın Etik Yönü}

Araştırmaya başlamadan önce, Girişimsel Olmayan Klinik Araştırmalar Etik Kurul'undan etik kurul onayı alınmıştır (Onay tarihi ve Kodu: 3 Aralık 2018-12/5 No’lu Karar). Bununla birlikte, araştırmanın 11 fakültede yapılacağına dair kurum izni (Say1: 99489383-302.08.01/ Onay tarihi: 18 Aralık 2018) ve çalışmaya katılmayı kabul eden öğrencilerden sözlü onam alınmıştır. Araştırmanın katılımcılara herhangi bir zarar verme riski söz konusu olmamıştır. Çalışma araştırma ve yayın etiğine uygun yürütülmüştür.

\section{Öğrencilerin Sosyo-Demografik Özellikleri}

\section{Bulgular}

Tablo 1'de araştırmaya katılan öğrencilerin sosyo-demografik özellikleri verilmiştir. Araştırma katılan öğrencilerin \%51.1'inin erkek, \%94.1'inin 25 yaş altında ve yaş ortalamasının 22.8 yıl olduğu belirlenmiştir. Örneklemde yer alan öğrencilerin çekirdek aileye sahip olma oranının \%79.5 olduğu, öğrencilerin en uzun süre yaşadığ yerleşim yerinin \%63.2 oranında il merkezi olduğu ve \%48.9'unun iki kardeşe sahip olduğu saptanmıştır. Aynı zamanda, öğrencilerin annelerinin \%56.4'ünün eğitim durumunun ilköğretim ve altı, babalarının \%62.8'inin lise ve üzeri olduğu belirlenmiştir.

Tablo 1. Üniversite Öğrencilerinin Sosyo-Demografik Özelliklerin Dă̆ılımı $(n=712)$

\begin{tabular}{|c|c|c|c|}
\hline & & $\mathbf{n}$ & $\%$ \\
\hline \multirow[t]{3}{*}{ Yaş } & 25 yaş ve altı & 670 & 94.1 \\
\hline & 26 yaş ve üzeri & 42 & 5.9 \\
\hline & Yaş ortalaması $=22.8$ & $($ Min. $=19$, Mak. = 36) & \\
\hline \multirow[t]{2}{*}{ Cinsiyet } & Kadın & 348 & 48.9 \\
\hline & Erkek & 364 & 51.1 \\
\hline \multirow[t]{3}{*}{ Aile tipi } & Çekirdek aile & 566 & 79.5 \\
\hline & Geniş aile & 118 & 16.6 \\
\hline & Parçalanmış aile & 28 & 3.9 \\
\hline En uzun yaşanılan & Köy & 64 & 9.0 \\
\hline \multirow[t]{3}{*}{ yerleşim yeri } & İlçe & 194 & 27.2 \\
\hline & İl merkezi & 450 & 63.2 \\
\hline & Diğer & 4 & 0.6 \\
\hline \multirow[t]{6}{*}{ Kardeş sayısı } & 0 & 54 & 7.6 \\
\hline & 1 & 348 & 48.9 \\
\hline & 2 & 174 & 24.4 \\
\hline & 3 & 78 & 11.0 \\
\hline & 4 & 25 & 3.5 \\
\hline & 5 ve üzeri & 33 & 4.6 \\
\hline \multirow[t]{2}{*}{ Anne eğitim durumu } & İlköğretim ve altı & 402 & 56.4 \\
\hline & Lise ve üzeri & 310 & 43.6 \\
\hline \multirow[t]{3}{*}{ Baba eğitim durumu } & İlköğretim ve altı & 265 & 37.2 \\
\hline & Lise ve üzeri & & \\
\hline & & 447 & 62.8 \\
\hline
\end{tabular}

\footnotetext{
* Satır yüzdesi kullanılmıştır.
}

\section{Öğrencilerin Gelecekte Çocuk Sahibi Olma Düşüncesi}

Öğrencilerin \%77.9'unun gelecekte çocuk sahibi olmak istediği, sahip olmak istedikleri çocuk sayısının ortalama 2.18 olduğu ve istenen çocuk sayısında cinsiyete göre farklılık oluşmadığı saptanmıştır (p = .101). Kadınların \%74.4'ünün, erkeklerin ise \%65.1'inin planladıkları ilk çocuğa sahip olma yaşı 25-29 yaş aralığıydı. Erkeklerin kadınlardan daha fazla oranda 30-34 yaş aralığında ilk çocuğa sahip olmak istediği belirlenmiştir $(\mathbf{p}=\mathbf{. 0 0 1})$. Geniş ailede yetişmiş öğrencilerin sahip olmayı planladıkları ortalama çocuk sayısının (2.55), çekirdek aile (2.09) ve parçalanmış ailede (2.28) yetişmiş öğrencilerden daha fazla olduğu saptanmıştır $(\mathbf{p}=\mathbf{. 0 0 0})$. En uzun süre yaşadığı yerleşim yeri köy olan öğrencilerin sahip olmayı planladığ 
ortalama çocuk sayısının (2.67), ilçe (2.18) ve il merkezinde (2.09) yaşamış öğrencilerden daha fazla olduğu belirlenmiştir ( $\mathbf{p}=$ .035).

\section{Öğrencilerin Gelecekte Çocuk Sahibi Olma Düşüncesini Etkileyen Faktörler ve Sosyo-Demografik Özellikleriİle İlişki \\ Durumu}

Tablo 2'de öğrencilerin gelecekte çocuk sahibi olma düşüncesini etkileyen faktörlere ilişkin ifadelere katılım oranları yer almaktadır. Öğrencilerin verdiği yanıtlar örneklem genelinde değerlendirildiğinde gelecekte çocuk sahibi olma düşüncesini etkileyen en önemli etkenin psikolojik iyilik hali (güzel duygular hissettirme, hayata bağlama, neşe katma, psikolojik doyum vs.) (\%86.6-\%56.5), sonrasında ise aile hayatı ve soyun devamı faktörleri (\%70.4-\%50.6) olduğu belirlenmiştir. Aynı zamanda çocuk sahibi olmanın bireysel bir tercih olduğu ve kadın istemedikçe çocuk sahibi olmaya zorlanmaması gerektiğine dair verilen ifadeler \%88.3-\%88.5 oranlarıyla grubun en çok katılım sağladığı ifadeler olarak belirlenmiştir. Aile büyükleri ve eşin istek-baskısı, erkek çocuk algısına ilişkin ifadeler ve çocuğu gelecek garantisi görmek öğrencilerin \%12.5-\%32.2 oranlarında katılım gösterdiği ve gelecekte çocuk sahibi olma düşüncesini en az etkileyen faktörler olduğu saptanmıştır. Öğrencilerin \%72.1'i ekonomik olarak özgür olmadığı takdirde çocuk sahibi olmak istemediğini belirtti (Tablo 2).

Tablo 3'e göre çalışmada erkek öğrencilerin kadın öğrencilere göre; toplumsal statü kazanma, aile hayatının ve soyun devamını sağlama açısından çocuk sahibi olmaya verdiği değerin istatistiksel olarak anlamlı düzeyde yüksek olduğu saptanmıştır.

Tablo 4’te öğrencilerin aile tipine göre gelecekte çocuk sahibi olma düşüncesini etkileyen faktörler arasındaki karşılaştırması verilmiştir. Araştırmada geniş aile tipine sahip öğrencilerin çocuk sahibi olmaya ilişkin verilen soyun devamı $(\mathrm{p}$ $=.031)$, aile işlerine destek $(\mathrm{p}=.015)$, gelecek garantisi $(\mathrm{p}=.015)$, dini inançlar $(\mathrm{p}=.006)$, bireysel karar verme $(\mathrm{p}=.008)$ başlıklı ifadelere katılımlarının diğer öğrencilere göre istatistiksel olarak anlamlı düzeyde yüksek olduğu saptanmıştır.

Tablo 5'te öğrencilerin en uzun süre yaşadığı yerleşim yerine göre gelecekte çocuk sahibi olma düşüncesini etkileyen faktörler arasındaki karşılaştırması verilmiştir. Verilen tabloya göre en uzun süre kırsal alanda yaşamış olan öğrencilerin çocuk sahibi olmaya ilişkin verilen soyun devamı $(\mathrm{p}=.039)$, aile işlerine destek $(\mathrm{p}=.000)$, gelecek garantisi $(\mathrm{p}=.015)$, dini inançlar $(\mathrm{p}=.021)$, erkek çocuk algısı $(\mathrm{p}=.002)$ ifadelerine katılımları diğer öğrencilere göre istatistiksel olarak anlamlı düzeyde yüksek saptanmışır. 
Tablo 2. Öğrencilerin Çocuk Sahibi Olma Düşüncesini Etkileyen Faktörlere İlişkin Bazı Bulgular (n= 712)

\begin{tabular}{|c|c|c|c|c|c|c|c|c|}
\hline Madde numarası & \multirow{3}{*}{$\begin{array}{l}\text { Öğrencilerin Çocuk Sahibi Olma Düşüncesini Etkileyen } \\
\text { Faktörler } \\
\text { ve ne kadar çocuk sahibi olacakları konusunda karar vermek } \\
\text { asal hakkıdır. }\end{array}$} & \multicolumn{2}{|c|}{ Katılmıyorum } & \multicolumn{2}{|c|}{ Kararsızım } & \multicolumn{2}{|c|}{ Katılıyorum } & \multirow[t]{2}{*}{ Etkileyen Faktör } \\
\hline & & $\mathrm{n}$ & $\% *$ & $\mathrm{n}$ & $\% *$ & $\mathrm{n}$ & $\% *$ & \\
\hline 1 & & 35 & 4.9 & 47 & 6.6 & 630 & 88.5 & Bireysel karar verme \\
\hline 3 & Çocuk sahibi olmak evliliğin devamlılığını olumlu etkiler. & 172 & 24.2 & 180 & 25.3 & 360 & 50.6 & Aile hayatının devamı \\
\hline 5 & Çocuk sahibi olmak bireylere güzel/pozitif duygular yaşatır. & 29 & 4.1 & 65 & 9.1 & 618 & 86.8 & Psikolojik iyilik \\
\hline 6 & Çocuk sahibi olmak soyu devam ettirmek için önemlidir. & 126 & 17.7 & 85 & 11.9 & 501 & 70.4 & Soyun devamı \\
\hline 7 & Düzenli bir işim olmadığı sürece çocuk sahibi olmak istemem. & 72 & 10.1 & 127 & 17.8 & 513 & 72.1 & Ekonomik yeterlilik \\
\hline 9 & Çocuk sahibi olmak hayata bağlılığı artırır. & 52 & 7.3 & 121 & 17.0 & 539 & 75.7 & Psikolojik iyilik \\
\hline 10 & Çocuk sahibi olmak eşlerin birbirine yakınlığını artırır. & 105 & 14.7 & 173 & 24.3 & 434 & 61.0 & Aile hayatının devamı \\
\hline 13 & Çocuğun varlığı eve ve aileye neşe katar. & 29 & 4.1 & 70 & 9.8 & 613 & 86.1 & Psikolojik iyilik \\
\hline 19 & Çocuk sahibi olmak bir kadınlık göstergesidir. & 486 & 68.3 & 136 & 19.1 & 90 & 12.6 & Statü kazanmak \\
\hline 20 & Çocuk sahibi olmak kadına toplumsal statü kazandırır. & 404 & 56.7 & 169 & 23.7 & 139 & 19.5 & Statü kazanmak \\
\hline 21 & Özellikle erkek çocuk sahibi olmak kadına/erkeğe aile ve toplumda prestij getirir. & 518 & 72.8 & 105 & 14.7 & 89 & 12.5 & Erkek çocuk algısı \\
\hline 23 & Özellikle erkek çocuk sahibi olmak aile kurumunun devamı için önemlidir. & 444 & 62.4 & 116 & 16.3 & 152 & 21.3 & Erkek çocuk algisı \\
\hline 26 & Çocuk sahibi olmayı istemede aile büyüklerinin baskısı önemli bir etkendir. & 428 & 60.1 & 169 & 23.7 & 115 & 16.2 & Aile ve çevre baskısı \\
\hline 31 & Çocuk sahibi olmamı sosyo-ekonomik durumum etkiler. & 111 & 15.6 & 158 & 22.2 & 443 & 62.2 & Ekonomik yeterlilik \\
\hline
\end{tabular}

\footnotetext{
*Satır yüzdesi alınmıştır
} 
Tablo 3.Öğrencilerin Cinsiyeti ile Çocuk Sahibi Olma Düşüncesini Etkileyen Faktörler Arasındaki İlişsije

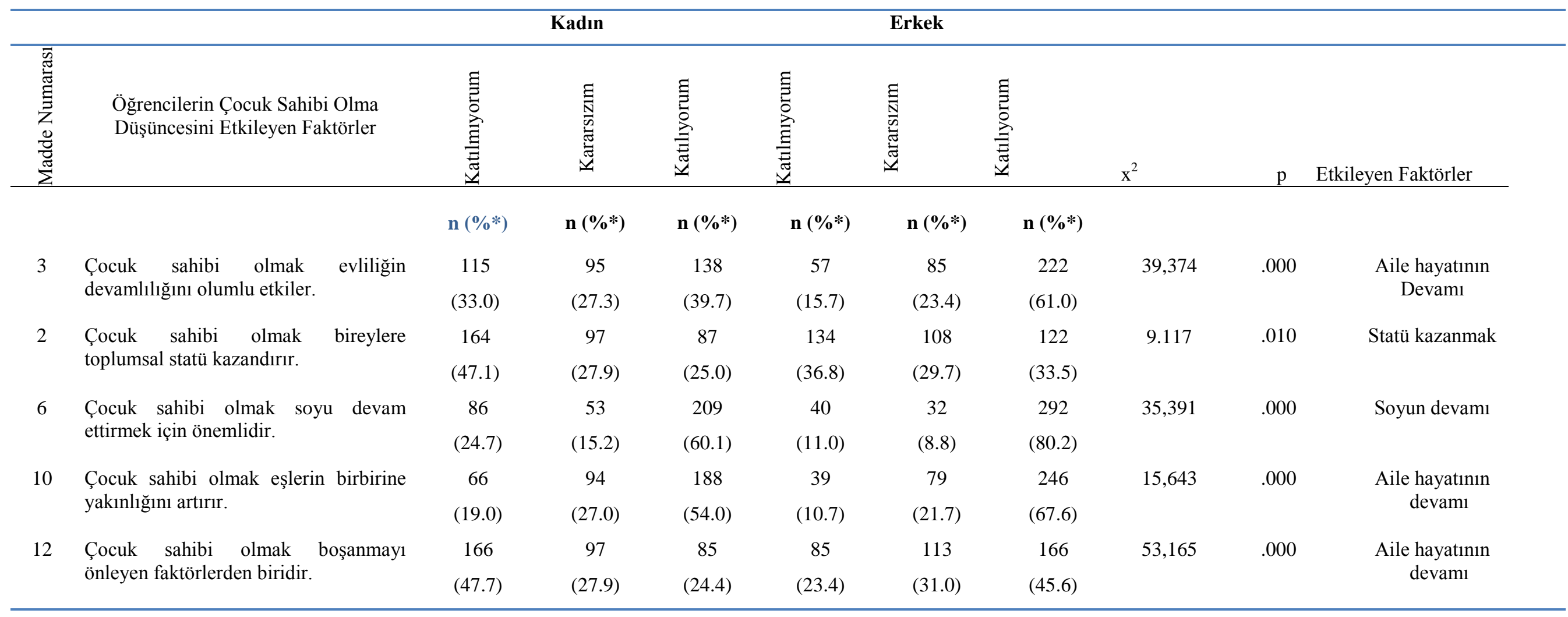

*Satır yüzdesi kullanılmıştır. 
Tablo 4. Öğrencilerin Aile Tipi ile Çocuk Sahibi Olma Düşüncesini Etkileyen Faktörler Arasındaki İlişkiye ait Bazı Bulgular (n = 712)

\begin{tabular}{|c|c|c|c|c|c|c|c|c|c|c|c|c|c|}
\hline \multirow[b]{2}{*}{ 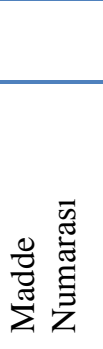 } & \multicolumn{5}{|c|}{$\begin{array}{c}\text { Çekirdek } \\
\text { Aile } \\
\end{array}$} & \multicolumn{2}{|l|}{$\begin{array}{c}\text { Geniş } \\
\text { Aile }\end{array}$} & \multicolumn{3}{|c|}{ Parçalanmış Aile } & \multirow[b]{2}{*}{$x^{2}$} & \multirow[b]{2}{*}{$\mathrm{p}$} & \multirow[b]{2}{*}{$\begin{array}{l}\text { Etkileyen } \\
\text { Faktörler }\end{array}$} \\
\hline & $\begin{array}{c}\text { Öğrencilerin Çocuk Sahibi } \\
\text { Olma Düşüncesini } \\
\text { Etkileyen Faktörler }\end{array}$ & 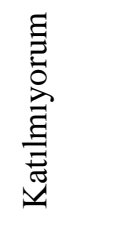 & 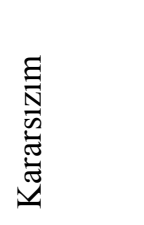 & 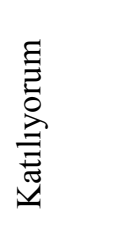 & 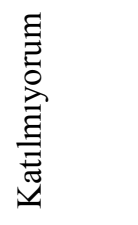 & 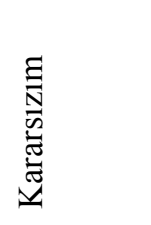 & 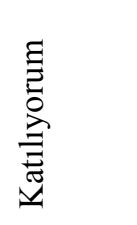 & 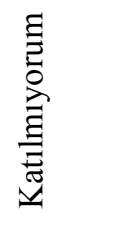 & 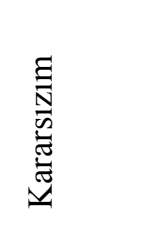 & 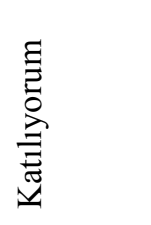 & & & \\
\hline & & $\begin{array}{c}\mathrm{n} \\
(\%)^{*}\end{array}$ & $\begin{array}{c}\mathrm{n} \\
(\%)^{*}\end{array}$ & $\begin{array}{c}\mathrm{n} \\
(\%)^{*}\end{array}$ & $\begin{array}{c}\mathrm{n} \\
(\%)^{*}\end{array}$ & $\begin{array}{c}\mathrm{n} \\
(\%)^{*}\end{array}$ & $\begin{array}{c}\mathrm{n} \\
(\%)^{*}\end{array}$ & $\begin{array}{c}\mathrm{n} \\
(\%)^{*}\end{array}$ & $\begin{array}{c}\mathrm{n} \\
(\%)^{*}\end{array}$ & $\begin{array}{c}\mathrm{n} \\
(\%)^{*}\end{array}$ & & & \\
\hline 6 & $\begin{array}{lcc}\text { Çocuk sahibi olmak } & \text { soyu } \\
\text { devam } & \text { ettirmek } & \text { için } \\
\text { önemlidir. } & & \end{array}$ & $\begin{array}{c}105 \\
(18.6)\end{array}$ & $\begin{array}{c}69 \\
(12.2)\end{array}$ & $\begin{array}{c}392 \\
(69.3)\end{array}$ & $\begin{array}{c}15 \\
(12.7)\end{array}$ & $\begin{array}{c}9 \\
(7.6)\end{array}$ & $\begin{array}{c}94 \\
(79.7)\end{array}$ & $\begin{array}{c}6 \\
(21.4)\end{array}$ & $\begin{array}{c}7 \\
(25.0)\end{array}$ & $\begin{array}{c}15 \\
(53.6)\end{array}$ & 10,650 & .031 & Soyun devam \\
\hline 7 & $\begin{array}{l}\text { Düzenli bir işim olmadığ } 1 \\
\text { sürece çocuk sahibi olmak } \\
\text { istemem. }\end{array}$ & $\begin{array}{c}47 \\
(8.3)\end{array}$ & $\begin{array}{c}104 \\
(18.4)\end{array}$ & $\begin{array}{c}415 \\
(73.3)\end{array}$ & $\begin{array}{c}20 \\
(16.9)\end{array}$ & $\begin{array}{c}22 \\
(18.6)\end{array}$ & $\begin{array}{c}76 \\
(64.4)\end{array}$ & $\begin{array}{c}5 \\
(17.9)\end{array}$ & $\begin{array}{c}1 \\
(3.6)\end{array}$ & $\begin{array}{c}22 \\
(78.6)\end{array}$ & 13,524 & .009 & $\begin{array}{l}\text { Ekonomik } \\
\text { yeterlilik }\end{array}$ \\
\hline 14 & $\begin{array}{l}\text { Çocuk sahibi olmak aile } \\
\text { işlerinde (ev, bağ, bahçe ve } \\
\text { diğer) destek için önemlidir. }\end{array}$ & $\begin{array}{c}198 \\
(35.0)\end{array}$ & $\begin{array}{c}152 \\
(26.9)\end{array}$ & $\begin{array}{c}216 \\
(38.2)\end{array}$ & $\begin{array}{c}24 \\
(20.3)\end{array}$ & $\begin{array}{c}31 \\
(26.3)\end{array}$ & $\begin{array}{c}63 \\
(53.4)\end{array}$ & $\begin{array}{c}10 \\
(35.7)\end{array}$ & $\begin{array}{c}8 \\
(28.6)\end{array}$ & $\begin{array}{c}10 \\
(35.7)\end{array}$ & 12,307 & .015 & $\begin{array}{c}\text { Aile işlerine } \\
\text { destek }\end{array}$ \\
\hline 25 & $\begin{array}{l}\text { Kadın istemiyorsa bile eşi } \\
\text { istediği için } \\
\text { doğurmalıdır. }\end{array}$ & $\begin{array}{c}477 \\
(84.3)\end{array}$ & $\begin{array}{c}54 \\
(9.5)\end{array}$ & $\begin{array}{c}35 \\
(6.2)\end{array}$ & $\begin{array}{c}84 \\
(71.2)\end{array}$ & $\begin{array}{c}17 \\
(14.4)\end{array}$ & $\begin{array}{c}17 \\
(14.4)\end{array}$ & $\begin{array}{c}24 \\
(85.7)\end{array}$ & $\begin{array}{c}3 \\
(10.7)\end{array}$ & $\begin{array}{c}1 \\
(3.6)\end{array}$ & 13,765 & .008 & $\begin{array}{c}\text { Bireysel karar } \\
\text { verme }\end{array}$ \\
\hline
\end{tabular}

*Satır yüzdesi kullanılmıştır. 
Tablo 5. Öğrencilerin En Uzun Yaşadıkları Yer ile Çocuk Sahibi Olma Düșüncesini Etkileyen Faktörler Arasındaki İlișkiye ait Bazı Bulgular (n = 712)

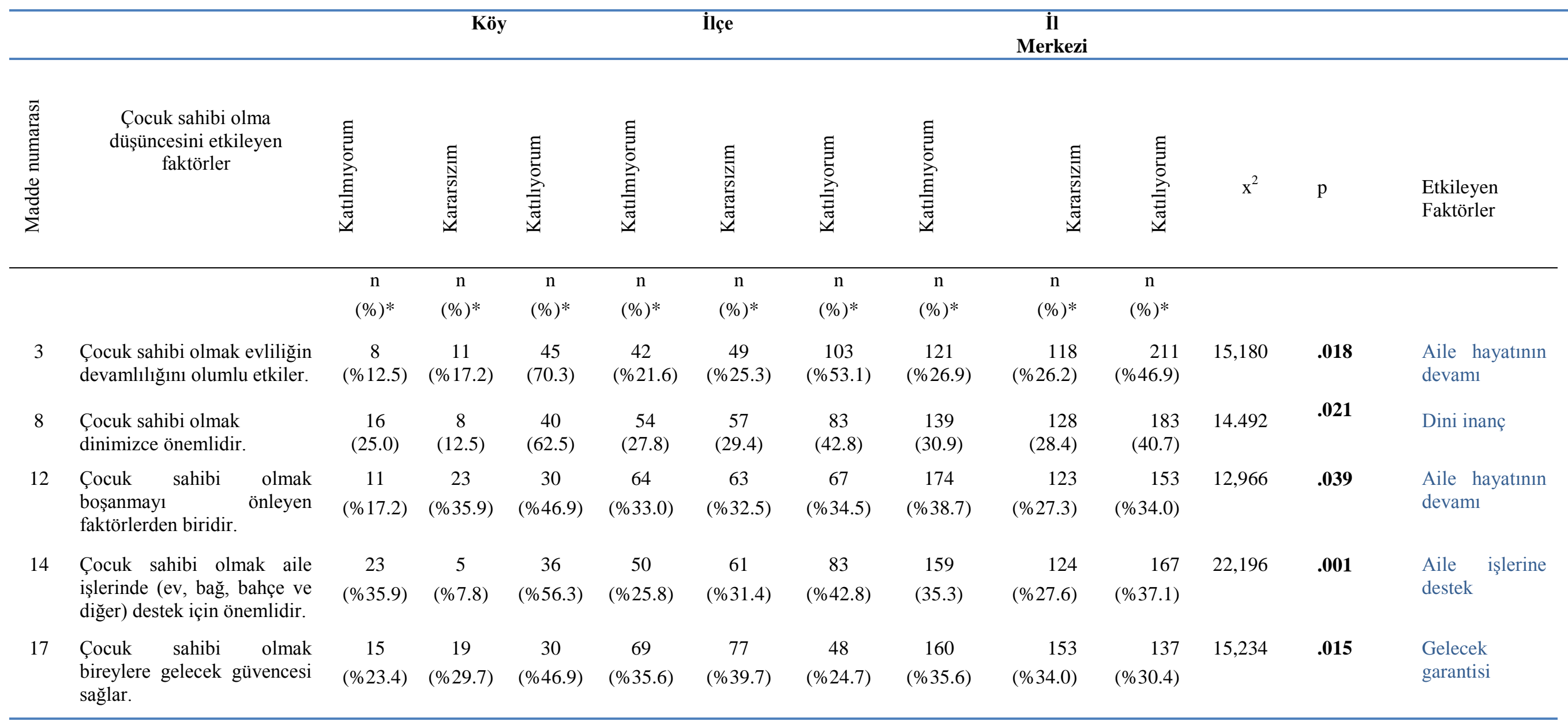

*Satır yüzdesi kullanılmışıtır. 


\section{Tartışma}

Aile çocuğun ilk karşılaştı̆̆ toplumsal yapı, kişiliğinin temellerini atacağ1 ilk birimdir $(9,12)$. Ailede çocuğa atfedilen değer ve beklentiler çocuğun kişilik özelliklerini ve toplumda nasıl bir birey olarak yer alacağını belirleyen temel unsurlardır. Bu nedenle toplumda çocuğa atfedilen değerin, bireylerin neden çocuk sahibi olmak isteyip-istemediğinin belirlenmesi son derece önemlidir (19). Aynı zamanda bireylerin çocuk sahibi olmaya yönelik yaklaşım ve düşüncelerinin belirlenmesi aile yapısı, gelecek planlaması, toplum yapısının analizi, nüfus politikaları gibi birçok konuda rehberlik etmesi açısından da önemlidir (14). Bu çalışma, Eskişehir'de bulunan bir üniversitede öğrenim gören öğrencilerin çocuk sahibi olma isteğini etkileyen faktörleri incelemek amacıyla yapıldı.

Çalışmada elde edilen bulgular 3 ana başlıkta tartışılmıştır.

1. Öğrencilerin Sosyo-Demografik Özelliklerine İlişkin Bulguların Tartışılması

2. Öğrencilerin Gelecekte Çocuk Sahibi Olma Düşüncesini Etkileyen Faktörlere İlişkin Bulguların Tartışılması

3. Öğrencilerin Sosyo-Demografik Özellikleri ile Gelecekte Çocuk Sahibi Olma Düşüncesini Etkileyen Faktörler Arasındaki İlişkiye Ait Bulguların Tartışılması

\section{Öğgrencilerin Sosyo-Demografik Özelliklerine İlişkin Bulguların Tartışılması}

Araştırmada öğrencilerin dörtte üçünden fazlasının gelecekte çocuk sahibi olmak istediği belirlenmiştir. Özerdoğan ve Yılmaz'ın (2018) öğrencilerin çocuk sahibi olmaya yönelik düşünce ve doğurganlık bilinçlerini belirmeye yönelik yaptığı çalışmada öğrencilerin \%88.45'inin, Ekelin ve ark.'nın (2012) çalışmasında \%97'sinin, Nouri ve ark.'nın (2014) çalışmasında \%77'sinin, Mogilevkina ve ark.'nın (2016) çalışmasında \%78'inin, Aşcı ve ark.'nın (2017) hemşirelik öğrencileri ile yaptığı çalışmada \%86.2'sinin gelecekte çocuk sahibi olmak istediği belirlenmiştir. Yapılan çalışmalara göre öğrencilerin gelecekte çocuk sahibi olma planları yaşadıkları ülkelerin refah düzeyi, sosyo-kültürel faktörleri ya da yürütülen politikalarla ilişkili olarak değişebilmektedir. Refah düzeyi yüksek veya sosyo-kültürel değerlere fazla bağlı ülkelerde gelecekte çocuk sahibi olmayı isteme oranı yüksek bulunurken $(15,20,23)$; refah düzeyi düşük veya orta seviyeli ülkelerde bu oran daha düşük bulunmuştur. $\mathrm{Bu}$ durum araştırmacılar tarafından ekonomik istikrarsızlık ve öğrencilerin geleceğini belirsiz görmesine bağlanmıştır (22). Bu çalışmaya katılan öğrencilerden gelecekte çocuk sahibi olma isteyenlerin oranı (\%77) ülkemizin mevcut sosyo- ekonomik durumuna bağlı yaşanan gelecek endişesine bağlanabileceği gibi, artan eğitim seviyesi ve kariyer planlamaları sonucu evlilik algılarının değişmesine ve çocuk sahibi olmanın ikinci plana atılmış olmasına da bağlanabilir. Bunun yanı sıra öğrencilerin gelecekte çocuk sahibi olma isteği öğrencilerin cinsiyetine göre anlamlı bir farklılık oluşturmamıştır.

Ülkemizde yürütülen nüfus politikaları ailelerin en az üç çocuk sahibi olmalarını istemekte ve nüfus büyüklüğünü bu şekilde korumayı hedeflemektedir (29). Çalışmada öğrencilerin gelecekte sahip olmak istediği çocuk sayısı ortalama önerilen sayıdan düşüktür ancak son açıklanan doğurganlık hızı verilerine yakınlık göstermektedir (28). Türkiye'de 1970'li yıllardan beri düşme eğiliminde olan doğurganlık hızı 2017 yılında 2,07 çocuk iken 2018 yılında 1,99 çocuk olarak saptanmıştır (27, 28). Farklı ülkelerde yapılan çalışmalar incelendiğinde gelecekte istenen çocuk sayısı benzer şekilde 2-3 arasında değişiklik göstermektedir $(23,24,25,26)$. Öğrencilerin yürütülen politikalardan çok fazla etkilenmediği; aksine çocuk sahibi olmanın iş ve kariyer planlarına engel olacağı düşüncesi ile sahip olmak istenen çocuk sayısını sınırlandırdıkları düşünülmektedir.

Çalışmada öğrencilerin yarıdan fazlasının ilk kez çocuk sahibi olmak için düşündüğü ideal yaş aralığının 24-29 yaş arasında olduğu belirlenmiştir. Türkiye'de en yüksek doğurganlık hızına sahip yaş aralığı 2008 yılına kadar 20-24 yaş iken, o yıldan bu zamana 24-29 yaş arasında yer almaktadır $(28,30)$. Ülkemizin mevcut şartlarında bir öğrencinin 22-26 yaş arasında mezun olduğu düşünüldüğünde, iş bulup hayatını düzene soktuktan sonra evlilik ve çocuk sahibi olmayı planlaması beklenen öğrenciler için bu yaş aralığı beklenen bir durumdur. Bunun yanı sıra çalışmada erkeklerin kadınlara göre ilk ve son çocuğa sahip olma yaşını daha ileri yaşlara erteledikleri görülmektedir. İlk çocuğa sahip olmak için 30-34 yaş arasını tercih eden erkeklerin oranı kadınlara göre istatistiksel olarak anlamlı şekilde yüksektir. Kadınların üreme özellikleri, doğurganlığın ilerleyen yaşlarda azalması ve geleneksel toplum yapısına göre kadınların erkeklere göre daha erken evlenmeleri gerektiği inancı göz önüne alındığında böyle bir sonucun çıkmış olması beklendik bir durum olarak değerlendirilmiştir. Toplumsal cinsiyet rolleri kapsamında bakıldığında ise erkeğe verilen temel rollerden biri de evin geçimini sağlamak ve ekonomik olarak rahat bir yaşam sunmaktır. Kadının çalışmaması göze çarpmazken erkekten mutlak çalışması, para kazanması ve ailesinin geçimini, düzenini sağlaması beklenir. Verilen bu sorumluluklar henüz okumakta olan ve gelecek belirsizliği yaşayan erkek öğrencilere ağır bir yük olarak gelebileceği gibi hayatını ve işini düzene soktuktan sonra daha ileri yaşlarda çocuk sahibi olmak istemelerini de açıklayabilir.

\section{Öğgrencilerin Gelecekte Çocuk Sahibi Olma Düşüncesini Etkileyen Faktörlere İlişkin Bulguların Tartışılması}

Çalışmada üniversite öğrencilerinin gelecekte çocuk sahibi olma düşüncesini etkileyen faktörler arasında çocuğun sağlayacağı psikolojik iyilik halinin en yüksek katılıma sahip etken olduğu saptanmıştır. Anne baba olmanın vereceği mutluluk, kendinden bir parça olarak görülen bebeğin varlığı, eve neşe katması, bireyin aldığı sorumluluk duygusu, ailesinin tamamlandığı hissi, toplumda yetişkin imajına sahip olma gibi tüm bu hisler psikolojik faktörler altında değerlendirilmektedir. Konuya ilişkin üniversite öğrencileri ile yapılmış çalışma bulunmamakla birlikte çocuk sahibi olma düşüncesi üzerine yapılmış çalışmalar anne-babalar veya yaş ortalaması yüksek kadın-erkek grupları ile yapılmış çalışmalardır. Kağıtçıbaşı ve Ataca (2005) tarafından yürütülmüş olan üst, orta ve düşük sosyoekonomik tabakalardan gelen; sadece kadın katılımcıların dahil edildiği ve toplamda 1025 kişiden oluşan çalışmada ya da Duman (2016) tarafindan Adana'da 183 kişilik genç anne-babaların oluşturduğu bir örneklemle yürütülmüş olan çalışmada bireylerin çocuk sahibi olma nedenlerinin başında psikolojik iyilik halinin yer aldığı belirtilmiştir. Geleneksel Türk toplumunun kültür yapısı düşünüldüğünde aynı zamanda çocuğa dair beslenen pozitif duygular da eklendiğinde öğrencilerin çocuk sahibi olma düşüncesini etkileyen önemli bir faktör olması beklenen bir sonuçtur. 
Araştırmada öğrencilerin gelecekte çocuk sahibi olma düşüncesini etkileyen etkenler arasında psikolojik iyilikten sonra aile hayatı ve soyun devamı faktörlerinin geldiği belirlenmiştir. Soyun devamı hem aile hem toplum hem de devlet için çok önem arz eden bir konudur. Bireyler için soyadını aktarmak, mirasını bırakmak aslında kendi varlığının bir şekilde devam etmesini sağlamak şahsi bir mesele olarak algılanmakta ve değer görmektedir. Devlet politikası olarak incelendiğinde ise kendi ırkının sürdürülmesi, ülke adının devamlılığı niteliğinde görülmekte ve çocuk sahibi olmak desteklenmektedir (29). Bunun yanı sıra Türk toplumunda aile kurmak ve o ailenin devamlılığını sağlamak da bir o kadar önemli görülmektedir. Toplumun temeli sayılan ailenin, çocuğun varlığıyla daha sağlam bir yapıya ulaştığı düşünülmektedir. Bireylerde oluşturduğu pozitif etki, sorumluluk bilinci, anne-baba olma heyecanı aile hayatına renk katan ve sürekliliğini artıran bir durum olarak görülmektedir. Hatta toplumda anlaşamadıkları halde çocukları için evliliğini sürdürmeye çalışan ya da evlilikteki sorunları çözebilmek için çocuk sahibi olan çiftler de sıklıkla karşımıza çıkmaktadır (33, 34). Kır ve Bülbül (2012)'ün yaptığ́ bir çalışmaya göre Türkiye'de boşanmaları engelleyen önemli faktörlerden biri, ailedeki çocuk sayısıdır. Çocuk yuvayı kurtaran, eşleri bir arada tutan bir bağ görevi görmektedir. Soyu devam ettirmek ve aile birliğinin devamlılığını sağlamak toplumda mutlak bir gereklilik olarak görülürken aynı toplumda yetişen öğrencilerin de bu kavramları önemli görmeleri beklenen bir sonuçtur.

Çalışmada üniversite öğrencilerinin büyük çoğunluğunun çocuk sahibi olma konusunda erkek çocuk algısına katılım sağlamadığı ve eşitlikçi bir tavır içinde olduğu saptanmıştır. Diğer bir deyişle öğrencilerin gelecekte çocuk sahibi olma düşüncesini etkileyen faktörler arasında erkek çocuk isteği son sıralarda yer aldı. Üniversite yılları yaş itibariyle bir bireyin geleneksel yapı kıskacından biraz daha uzak kalabildiği, aile ve çevre baskısıyla henüz çok fazla muhatap olmadığı ve idealist düşüncelerin en zirvede olduğu dönemdir. Elde edilen bu bulgu örneklem grubunun yaş ve eğitim durumu özelliği nedeniyle beklenen bir sonuçtur. Ancak bu çalışma toplumun farklı katmanlarında yapıldığında cinsiyet rolüne ilişkin ifadelere katılım oranının daha yüksek olacağı tahmin edilmektedir. Çünkü ataerkil ideolojiye göre kadının en önemli görevlerinden biri çocuk doğurmak ve soyun devamını sağlamaktır. Soyun devamını sağlayan ise erkek çocuktur (35). Üniversite öğrencilerinin aksine yaş grubu daha yüksek ve eğitim seviyesi daha düşük bir grupta yapılan çalışmada kadınlar erkek çocuğun soyun devamı için, eşlerinin şanı ve kendi aile içi konumları için çok değerli olduğunu belirtmiştir (36). Geleceğin birçok meslek grubunda yer alıp ülkemizi temsil edecek aynı zamanda anne-baba olmaya, yeni bireyler yetiştirmeye en yakın grup olan üniversite öğrencilerinin cinsiyet rolleri açısından eşitlikçi düşüncelere sahip olması olumlu bir sonuç olarak değerlendirilmiştir.

Çalışmada ortaya çıkan diğer önemli bir sonuç ise öğrencilerin kendini ekonomik olarak yeterli hissetmeden ya da iş yaşantıları uygun olmadan çocuk sahibi olmak istememeleridir. Zaman içerisinde değişen ve modernleşen toplumun getirisi olarak artan kadın okullaşma ve istihdam oranları, aynı zamanda gençlerin kariyer hedefleri, yakalamak istedikleri hayat standartları gibi faktörlerin bu düşünceye sahip olmalarında etkili olduğu düşünülmektedir. Ülkemizde iş bulmanın, standart şekilde bir geçim sağlamanın dahi zorlukları düşünüldüğünde öğrencilerin bu durumlardan etkilendiği düşünülebilir.

Geleneksel Türk toplumu yapısında "evlat” anlayışı hakimdir ve bu anlayışa göre de "evlat anne-babaya destek olur, yalnız bırakmaz, maddi güvence sağlar". Daha ileri yaş grubu ile yapılan çalışmalarda evli çiftlerin aile büyüklerinin baskı ve isteklerinden çok fazla etkilendiği görülmektedir $(16,37)$. Özellikle kırsal alanlarda yaşayan ve geniş aile yapısına sahip ailelerde aile büyüklerinin isteklerine çok önem verilmektedir. Geleneksel ve ataerkil yapıya göre birçok nedenle çocuk sahibi olmak önemli görülmekte ve gençler tarafından da büyüklerden gelen bu isteklerine saygı duyması beklenmektedir. Çalışmamızda ise aile büyükleri ve eşin istek-baskıları öğrencilerin gelecekte çocuk sahibi olma düşüncesini etkileyen faktörler arasında alt sıralarda yer aldı. Araştırmamızın bu sonucu öğrencilerin henüz bulundukları durum itibariyle evlilik ve aile hayatının biraz daha dışında yer almalarından kaynaklanmış olabilir.

\section{Ö̆̆rencilerin Sosyo-Demografik Özellikleri ile Gelecekte Çocuk Sahibi Olma Düşüncesini Etkileyen Faktörler Arasındaki} Ilişkiye ait Bulguların Tartışılması

Çalışmada cinsiyet faktörünün öğrencilerin sahip olmak istediği çocuk sayısı üzerine anlamlı bir etkisi bulunmazken, ilk kez çocuk sahibi olmak için ideal yaş aralığı tercihinde istatistiksel olarak anlamlı fark oluşturduğu saptanmıştır. İlk kez çocuk sahibi olmak için erkeklerin kadınlara oranla daha ileri yaş aralığını tercih ettiği tespit edildi. Kadınların üreme özellikleri ve toplumsal yapı etkeni göz önüne alındığında erkeklerden yaşça daha erken evlenmeleri gerektiği inancı da eklendiğinde böyle bir sonucun çıkmış olması beklendik bir durum olarak değerlendirilmiştir. Bunun yanı sıra verilen toplumsal statü kazanma, aile hayatının ve soyun devamını sağlamaya yönelik ifadelere erkek öğrenciler daha fazla katılım sağlamıştır. Duman (2016)'ın yaptığı çalışmada da erkek bireylerin soyun devamı, aile kurmak gibi sosyo-kültürel faktörlere daha fazla destekleyici olduğu belirlenmiştir. Geleneksel toplum yapısının erkeğe yüklediği temel sorumluluklar düşünüldüğünde erkek öğrencilerin verdiği yanitlar beklendik bir tablodur.

Çalışmada geniş aile tipine sahip öğrencilerin çekirdek ve parçalanmış aile tipine sahip öğrencilere göre; en uzun süre yaşadiğ yerleşim yeri köy olan ögrencilerin ise ilçe ve il merkezi olan ögrrencilere göre daha fazla sayıda çocuk sahibi olmak istediği saptanmıştır. Bunun yanı sıra bu öğrenciler erkek çocuk sahibi olmayı soyun devamı, dini inanç ve aile işlerine destek sağlama açısından daha önemli gördüler. Köy yaşamı ve geniş aile şeklinde yaşamak birbirini destekleyen iki kavramdır. Geniş ailenin hakim olduğu evli kadın gruplarıyla yapılan çalışmalarda çocuk sahibi olmanın erkeğin şanını yücelttiği, soyu devam ettirdiği ve tarımda iş gücü olacak eleman sağladığı aynı zamanda dinen de gerekli olduğu ortaya konmuştur $(17,36)$. Geniş aile, geleneksel düşünce yapısının ve birtakım dini inançların çekirdek ve parçalanmış ailelere göre daha yaygın olduğu bir aile tipidir. Bunun yanı sıra köyler çocuğa maddi-manevi daha çok anlam yüklenen yerleşim yeridir (11). Dolayısıyla soyun devam etmesi, dini inançlara sahip çıkılması ve aile içinde hiyerarşiye uygun şekilde herkesin üzerine düşen iş ve görevi yerine getirmesi son derece önemlidir. Geniş ailelerde kalabalık nüfusa sahip olmak da bir gereklilik olarak görüldüğü için soyun devam etmesi açısından çocuk sahibi olmak özellikle erkek çocuk sahibi olmak ayrı bir önem taşımaktadır. Ayrıca geniş aileler veya köyde yaşayan aileler geçimini büyük oranda tarımsal yollardan karşıladığı için büyükküçük ayrımı yapılmaksızın tüm işler aile üyeleri arasında paylaştırılmaktadır. Erkek çocuğundan babanın işlerini devralması, 
tarlayı işlemesi ve aileye bakması beklenirken kız çocuğundan da ev işlerini yapması, anneye destek olması beklenmektedir. Çocuğa da bu anlamda fiziksel güç ihtiyacını karşılaması için temel bir ihtiyaç gözüyle bakılmaktadır (7). Aynı zamanda hem hukuken hem de ataerkil düşünce yapısına göre baba soyuna dayalı, erkeğin soyadının aktarıldığı bir sistem hakimdir. Bu nedenle de soyun devam etmesi erkek çocuğuna bağlı görülmekte ve erkek çocuğuna daha fazla değer verilmektedir $(7,36)$. Bunun yanında ülkelerin geleneksel ve daha çok dine dayalı bir yönetim anlayışına hakim olmaları bireyleri çocuk sahibi olmaya teşvik edici bir etken olabileceği düşünülmektedir. Tüm bunlar sonucunda çalışmada öğrencilerin bu ifadelere yüksek oranda katılım sağlamış olması yetiştikleri aile ortamında gördükleri işleyiş ve düzenden, yaşadıkları ülkede yürütülen aileye ve çocuğa ilişkin politikalardan etkilenmelerine bağlanabilir.

\section{Kisitlılıklar}

Literatürde öğrencilerin çocuk sahibi olma isteğini etkileyen faktörleri inceleyen çalışmalara rastlanılmamıştır. Bu nedenle bu çalışma sonuçlarının literatürle tartışılmasında yetişkin bireylerin çocuk sahibi olmaya yönelik düşüncelerini inceleyen sınırlı sayıda çalışma sonuçları ve bulguları kullanılmıştır. Bu çalışma için bu durum bir sınırlılık oluşturmuştur.

\section{Sonuçların Uygulamada Kullanımı}

Çalışmamızda öğrencilerin büyük bir kısmının çocuk sahibi olmak istediği fakat gelecek kaygılarının olduğu bu nedenle de ekonomik özgürlüğünü sağlamadan çocuk sahibi olmak istemedikleri saptandı. Çalışmaya katılan öğrenciler çocuk sahibi olmanın toplumsal statü kazandıracağı düşüncesini önemsemezken; bireysel anlamda çevre edinme, sosyal ortam oluşturma ve bu bağlamda sosyalleşme sağlayacağı düşüncesini önemli gördükleri belirlendi. Çocuk sahibi olma düşüncesini etkileyen faktörler arasında geniş aile tipine sahip olma ve uzun süre kırsal alanda yaşamış olmanın önemli bir etkisi olduğu saptandı. Bu öğrencilerin gelecekte çocuk sahibi olmaya ilişkin verilen soyun devamı, aile işlerine destek, gelecek garantisi, dini inançlar, erkek çocuğun ayrıcalığı gibi ifadeleri diğer öğrencilere göre daha fazla önemli gördükleri belirlendi.

Çalışma sonuçlarına bakıldığında üniversitelerde öğrencilerin eğitim sürecinde; erkek çocuğun önemini vurgulayan toplumsal yetişmişliğin aksine toplumsal cinsiyet eşitliği bilincinin geliştirilmesine, sosyal ve ekonomik yeterliliğin daha sağlıklı bir ebeveyn olmadaki önemine ve çocuk sahibi olmada bireysel kararların toplumun ve ailenin beklentisinden daha önemli olduğuna ilişkin bilgileri içeren derslere yer verilmesi bireysel farkındalık yaratmak açısından önemli olacağı düşünülmektedir. Bunun yanı sıra çocuk sahibi olma düşüncesini ve etkilen faktörleri bilmek hemşirelerin üniversite öğlencilerinde farkındalık kazandırma sürecinde hangi faktörleri elle alması ve geliştirmesi gerektiğini görebilmek açısından çalışma sonuçlarını uygulamaya katkı sağlayacaktır.

Son olarak ileride bu konuda yapılacak çalışmalar için farklı gruplarla, daha kapsamlı ve mix metod kullanarak yapılmasının gerekliliği ve önemi anlaşılmıştır. Gelecekte bu konuda çalışma yapacak kişilerin bu öneriyi göz önünde bulundurmaları daha detaylı veri elde etmek açısından yararlı olacaktır.

\section{Bilgilendirme}

Bu çalışmada katkı oranı birinci yazar için \%60, ikinci yazar için \%40’dır. Tüm yazarlar eşit oranda katkı sağlamıştır. Araştırma için Girişimsel Olmayan Klinik Araştırmalar Etik Kurul'undan etik kurul onayı alınmıştır (Onay tarihi ve Kodu: 3 Aralık 2018-12/5 No’lu Karar). Bu araştırma yüksek lisans tezinden üretilmiştir. Araştırmaya herhangi bir fon desteği bulunmamaktadır. Yazarlar arasında herhangi bir çıkar çatışması bulunmamaktadır.

\section{Kaynaklar}

1. Aluş Y, Selçukkaya S. Türk ailesinde mutluluk algısı ve değerleri. Sosyal ve Kültürel Araştırmalar Dergisi 2015;1(2):151-175.

2. Günay $G$, Bener Ö. Gençlerin evlilik ve aile yaşamına ilişkin tutumları. Karabük Üniversitesi Sosyal Bilimler Enstitüsü Dergisi 2013;3(1):1-16.

3. Yapıcı Ş. Türk toplumunda aile ve eğitim ilişkisi. Turkish Studies Academik Journal 2010;5(4):1544-1570.

4. Aydın M. Ailede çocuk ve ebeveynle ilişkisi. İçinde Aydın M, Sistematik aile sosyolojisi. 3. Basım. Konya Çizgi Kitabevi;2016.195-210.

5. Aluş Y. Kültürel ve toplumsal gerçekliğimiz açısından aile anlayışlarının ve türk ailesinin değerlendirmesi. Pesa Uluslararası Sosyal Araştırmalar Dergisi 2015;1(1):15 24.

6. Özbay F. Kadının statüsü ve doğurganlık: Türkiye'de kadın olgusu. İstanbul Say Yayınları. 1992;147-165.

7. Taylan HH. Türkiye'de köy ailesinde aile içi ilişkiler. Selçuk Üniversitesi Edebiyat Fakültesi Dergisi 2009; 22:117-138.

8. Inglehart RC, Haerpfer A, Moreno C, Welzel K, Kizilova J, Diezmedrano M, Lagos P, Norris E, Ponarin B, Puranen et al. (eds.) 2014; World values survey: round six -country-pooled datafile 2010-2014. http://www.worldvaluessurvey.org/wvs.jsp Madrid: JD Systems Institute.

9. Erkut Z, Balcı S, Yıldız S. Tarihsel süreç içinde çocuk. Çocuk ve Medeniyet Dergisi 2017;2(3):17-28.

10. Behjati-Ardakani Z, Navabakhsh M, Hosseini SH. Sociological study on the transformation of fertility and childbearing concept in 1ran. Journal of Reproduction \& İnfertility 2017;18(1):153-161.

11. Kağıtçıbaşı Ç. Çocuğun Değeri: Türkiye'de değerler ve doğurganlık. İstanbul Boğaziçi Üniversitesi, İdari Bilimler Fakültesi. 1981;72-126.

12.Türk Dil Kurumu. Çocuk kavramının tanımı. Erişim Tarihi: 25.03.2019 Erişim Adresi: https://sozluk.gov.tr/?kelime=V\%09EK\%C4\%B0L 
13. Kağıtçıbaşı Ç. Benlik, aile ve insan gelişimi: Kültürel Psikoloji. 5. Basım. İstanbul: Koç Üniversitesi Yayınları; Eylül 2019.180-375.

14. Turgut M, Feyzioğlu S. Türkiye aile yapısı araştırması: tespitler, öneriler. Tc Aile ve Sosyal Politikalar Bakanlığı Araştırma ve Sosyal Politika Serisi, Ankara; 2014.150-183.

15. Aşcı Ö, Gökdemir F, Altuntaş G. Hemşirelik öğrencilerinin çocuk sahibi olmaya yönelik görüşleri ve çocuk sevme durumları. Uluslararası Hakemli Hemşirelik Araştırmaları Dergisi 2017;(10):18-35. Doi:10.17371/Uhd2017.2.02

16. Dinç Kahraman S. Kadınların toplumsal cinsiyet eşitsizliğine yönelik görüşlerinin belirlenmesi. Dokuz Eylül Üniversitesi Hemşirelik Yüksekokulu Elektronik Dergisi 2010;3(1):30-35.

17. Gücük S, Arıca SG, Akan Z, Arıca V, Alkan S. Van ilindeki çok eşlilik oranları ve etkileyen faktörler: kesitsel çalışma. Kartal Eğitim ve Araştırma Hastanesi Tıp Dergisi 2010;21(3):127-133.

18. İçli G.Yaşlılar ve yaşlılığın değerlendirilmesi: Denizli ili üzerine niteliksel bir araştırma. Yaşlı Sorunları Araştırma Dergisi 2010;3(1-2):1-13.

19. Kağıtçıbaşı Ç, Ataca B. Value of children, family change, and implications for the care of the elderly. Cross-Cultural Research 2015;49(4):374-392.

20. Özerdoğan N, Y1lmaz B. Turkish university seniors' knowledge of and opinions on fertility and expectations of having children. African Health Sciences 2018;18(1):172-179.

21. Nouri K, Huber D, Walch K, Promberger R, Buerkle B, Ott J et al. Fertility awareness among medical and non- medical students:a case-control study. Reproductive Biology and Endocrinology 2014; 12(1):94.

22. Mogilevkina I, Stern J, Melnik D, Getsko E, Tydén T. Ukrainian medical students' attitudes to parenthood and knowledge of fertility. The European Journal of Contraception \& Reproductive Health Care, 2016;21(2):189-194.

23. Ekelin M, Akesson C, Angerud M, Kvist LJ. Swedish high school students' knowledge and attitudes regarding fertility and family building. Reproductive Health 2012;9(6):1-8.

24. Lampic C, Svanberg AS, Karlström P, Tyden T. Fertility awareness, intentions concerning childbearing and attitudes towards parenthood among female and male academics. Human Reproduction 2005; 21(2):558-564.

25. Vassard D, Lallemant C, Nyboe Andersen A, Macklon N, Schmidt L. a Population-Based Survey on Family intentions and fertility awareness in women and men in the united kingdom and denmark. Upsala Journal of Medical Sciences 2016;121(4):244-251.

26. Virtala A, Vilska S, Huttunen T, Kunttu K. Childbearing the desire to have children and awareness about the impact of age on female fertility among finnish university students. The European Journal of Contraception \& Reproductive Health Care; 2011;16(2):108-115.

27. Türkiye İstatistik Kurumu 2017. Doğum istatistikleri 2016. Türkiye İstatistik Kurumu Haber Bülteni, 27588. Erişim Adresi: http://www.tuik.gov.tr/PreHaberBultenleri.do?id=27588 Erişim Tarihi: 25.03.2019.

28. Türkiye İstatistik Kurumu 2018. Doğum istatistikleri 2017. Türkiye İstatistik Kurumu Haber Bülteni, 30696. Erişim Tarihi: 25.03.2019 Erişim Adres: http://tuik.gov.tr/PreHaberBultenleri.do;jsessionid=ZtCppXBSRXGP7mFgPn8XQ20KXxNpk2tgNp8r6whdPbbj9d1QFKCS!1 206792011 ? id=30696

29. Kaya V, Yalçınkaya Ö. Nüfus ekonomik büyüme kaynağı olabilir mi ? "En az üç çocuk” politikasına tarihsel bakış. Atatürk Üniversitesi İktisadi ve İdari Bilimler Dergisi, 2014;28(1):165-198.

30. Türkiye İstatistik Kurumu 2009. Doğum istatistikleri 2001-2008 Yılı Sonuçları. Türkiye İstatistik Kurumu Haber Bülteni. 180. Erişim Tarihi: 25.03.2019 Erişim Adresi: http://tuik.gov.tr/PreHaberBultenleri.do?id=6164

31. Kağıtçıbaşı Ç, Ataca B. Value of children and family change: a three- decade portrait from Turkey. Applied Psychology 2005;54(3):317-337.

32. Duman M. Çocuğun değeri: Adana araştırması, Yüksek Lisans Tezi, Çağ Üniversitesi Sosyal Bilimler Enstitüsü, Mersin 2016.

33. Kır İ, Bülbül Ö. İslâhiye ilçesinde boşanma olgusu üzerine sosyolojik bir inceleme. Kahramanmaraş Sütçü İmam Üniversitesi Sosyal Bilimler Dergisi 2012;9(2):99-122.

34. Karadeniz H. Kadın ve aile hayatı. 1.basım. Nazım Elmas. Ankara: Pegem Akademi; Ağustos 2017. 181-220.

35. Karaoğlan S, Duman MZ. Dini inanç ve tutumların doğurganlık üzerindeki etkileri (van ili örneği). Journal of International Social Researc 2017;10(50):391-404.

36. Karakaya E, Coşkun AM, Özerdoğan N, Yakıt E. Suriyeli mülteci kadınların doğurganlık özellikleri ve etkileyen faktörler: kalitatif bir çalışma. Journal of International Social Research 2017;10(48):417-428.

37. Uğur SB. Geçmişten günümüze şekillenen çocukluk algısı ve çocuk yetiştirme pratikleri. Süleyman Demirel Üniversitesi Fen-Edebiyat Fakültesi Sosyal Bilimler Dergisi 2018;1(45):227-247. 